Fidei: Jurnal Teologi Sistematika dan Praktika, Vol. 4, No. 2, Des. 2021

Fidei: Jurnal Teologi Sistematika dan Praktika

Terakreditasi No: 85/M/KPT/2020 (Sinta 4)

e-ISSN: 2621-8135

http://www.stt-tawangmangu.ac.id/e-journal/index.php/fidei

Vol. 4 No.2 (Des. 2021) hlm: 183-205

p-ISSN: $2621-8151$

Diterbitkan Oleh: Sekolah Tinggi Teologi Tawangmangu

DOI: https://doi.org/10.34081/fidei.v4i2.204

\title{
Spiritualitas Alkitabiah Sebagai Hakikat Kepemimpinan Kristen Masa Kini
}

\author{
Yosep Belay, Yanto Paulus Hermanto, Rivosa Rivosa ${ }^{1{ }^{*}}$ \\ $\left.{ }^{1}\right)$ Sekolah Tinggi Teologi Kharisma, Indonesia \\ *) E-mail: yosep.belay@gmail.com
}

Diterima: 09 Des. 2020

Direvisi: 25 Nov. 2021

Disetujui: 29 Nov. 2021

\begin{abstract}
Abstrak
Ragam teori kepemimpinan umumnya berorientasi pada pengembangan karakter, skill dan manajemen kepemimpinan dengan penekanan yang kuat pada sisi pragmatis. Berbeda dengan pendekatan teori tersebut, prinsip Alkitab menekankan pada nilai-nilai spiritualitas sebagai pondasi kepemimpinan Kristen. Signifikansi spiritualitas menjadi permasalahan sekaligus unsur fundamental bagi konsep kepemimpinan Kristen masa kini sebagaimana yang dikaji dalam tulisan ini. Metode yang digunakan adalah kualitatif deskriptif dengan pendekatan studi kepustakaan (library research) dan komparasi. Melalui analisis studi ini, dijumpai bahwa terdapat dua pola dasar kepemimpinan yang berbeda antara konsep Alkitab dan kecenderungan para pemimpin Kristen masa kini. Alkitab menekankan pada fondasi spiritualitas dengan visi Allah sebagai penggerak tujuan akhir, sementara gagasan kepemimpinan Kristen saat ini cenderung menggunakan teori kepemimpinan sekuler dengan penekanan yang kuat pada hal-hal pragmatis yang antroposentris sebagai tujuan akhirnya.
\end{abstract}

Kata-Kata Kunci: Alkitabiah; Kepemimpinan; Kristen; Spiritualitas.

\section{Abstract}

Various leadership theories are generally oriented towards character development, skills, and leadership management with a strong emphasis on the pragmatic side. In contrast to the theoretical approach, the biblical principles 
emphasize the values of spirituality as the foundation of Christian leadership. The significance of spirituality is a problem as well as a fundamental element for the concept of contemporary Christian leadership as studied in this paper. The method used is descriptive qualitative with library research and a comparative approach. Through the analysis of this study, it was found that two basic patterns of leadership differ between the biblical concept and the tendencies of contemporary Christian leaders. The Bible emphasizes the foundation of spirituality with the vision of God as the driving force of the ultimate goal, while the current Christian leadership ideas tend to use secular leadership theories with a strong emphasis on anthropocentric pragmatic things as the ultimate goal.

Keywords: Biblical; Christian; Leadership; Spirituality.

\section{Pendahuluan}

Perkembangan kebudayaan saat ini memainkan peranan penting dalam menentukan rumusan dan arah serta tujuan suatu teori yang dikembangkan. Dalam rumusan-rumusan teoritis apa pun salah satu unsur utama yang paling menonjol adalah penekanan pada sisi pragmatis. Di dalam konsep teori mengenai kepemimpinan, semangat pragmatisme ini juga dimanifestasikan dalam beragam bentuk. Beberapa karya mengenai teori kepemimpinan memberikan gambaran yang rill tentang hal ini. Carol O'Connor dalam bukunya "Kepemimpinan yang Sukses Dalam Seminggu," mengajukan tujuh prinsip dasar untuk menjadi pemimpin dalam satu minggu. Prinsip-prinsip itu dikonstruksikan secara bertahap dari hari minggu, mengenai kesadaran diri, senin, mengenai memahami orang lain, selasa, perihal komunikasi, rabu, wewenang dan kekuasaan. Hari kamis, membuat keputusan, jumat, terhubung dan terikat, sabtu, visi dan inspirasi. ${ }^{1}$ Tujuan yang hendak dicapai yaitu sebuah model kepemimpinan yang sukses secara instan.

Dengan metode yang berbeda namun masih pada penekanan yang serupa, Jim Clemmer mengajukan beberapa prinsip abadi kepemimpinan dalam bukunya "Sang Pemimpin." Buku Clemmer tersebut menjabarkan mengenai sembilan sub tema yang dimulai dengan pemimpin membuat perbedaan, fokus dan konteks, tanggung jawab atas pilihan-pilihan, keautentikan, kemauan dan komitmen, semangat dan makna, menumbuhkan dan mengembangkan,

${ }^{1}$ Carol O’ Conner, Kepemimpinan Yang Sukses Dalam Seminggu (Jakarta: Indeks, 2014), 
memobilisasi dan memperkuat, serta kepemimpinan dan tindakan. ${ }^{2}$ Rujukan akhirnya masih seputar karakteristik pemimpin yang unggul. Buku kepemimpinan lain yang ditulis oleh David T. Kyle, hanya mengajukan empat prinsip dasar yaitu: kehadiran, tekad, kebijaksanaan dan rasa iba. ${ }^{3}$ Dengan pendekatan tersebut, para pemimpin diharapkan dapat mengelola kenyataan dalam situasi saat ini dengan visi mengenai hasil yang hendak dicapai. ${ }^{4}$ Merangkum sejumlah pandangan para ahli kepemimpinan, Kartini Kartono juga mengajukan ragam karakteristik seorang pemimpin dengan prinsip-prinsip yang masih berkaitan seputar skill, karakter, intelektualitas dan relasional kepemimpinan ${ }^{5}$ yang mana meskipun berbeda dengan sedikit variasi bahasan namun inti gagasannya masih tetap sama. Demikian juga dengan Maxwell, pionir kepemimpinan dalam bukunya "21 Ciri Pokok Seorang Pemimpin." Di dalam buku tersebut, Maxwell mengemukakan dua puluh satu ciri pemimpin yang semuanya berkaitan dengan pengembangan diri serta perihal manajemen relasional. ${ }^{6}$ Pada bagian pengantarnya, secara terus terang Maxwell menjelaskan bahwa ia sengaja menulis buku tersebut sebagai panduan pengembangan diri serta karakter seorang pemimpin agar orang lain ingin mengikuti. ${ }^{7}$ Perlu dikonfirmasi bahwa konten dan tujuan penulisan buku-buku tersebut pada dasarnya bersifat sekuler (non Kristen) karena ditujukan bagi publik umum, namun perlu diperhatikan juga bahwa gagasan-gagasan utamanya menekankan pada sisi pragmatis dan tendensi antroposentris yang sangat eksplisit. Keempat literatur ini dapat memberikan gambaran umum mengenai kerangka teori kepemimpinan sekuler secara umum dan orientasinya.

Berangkat dari rumusan para ahli yang menerangkan perihal kepemimpinan sebagai usaha untuk mempengaruhi orang lain dalam mencapai tujuan yang telah ditetapkan bersama ${ }^{8}$ namun di dalam satu wawasan dunia sekuler yang mengabsenkan spiritualitas Alkitabiah, maka pendekatan, strategi

${ }^{2}$ Jim Clemmer, Sang Pemimpin: Prinsip Abadi Untuk Keberhasilan Tim Dan Organisasi (Yogyakarta: Kanisius, 2009), 3.

${ }^{3}$ David T. Kyle, The Four Power of Leadership (Batam: Kharisma Press, 2004), 11.

${ }^{4}$ Ibid., 21.

${ }^{5}$ Kartini Kartono, Pemimpin Dan Kepemimpinan: Apakah Kepemimpinan Abnormal Itu? (Depok: Rajawali Press, 2016), 43-50.

6 John C. Maxwell, 21 Ciri Pokok Seorang Pemimpin: Buatlah Orang Lain Ingin Mengikuti Anda (Surabaya: MIC, 2014), v.

${ }^{7}$ Ibid., ix.

${ }^{8}$ Sonny Eli Zaluchu, "Respons Tests Of Leadership Menurut Frank Damazio Pada Mahasiswa Pascasarjana Jurusan Kepemimpinan Kristen STT Harvest Semarang," Jurnal Jaffray 16 (2018):148, https://doi.org/https://ojs.sttjaffray.ac.id/index.php/JJV71/article/view/289. 
dan tujuan akhirnya akan bermuara pada persepsi presuposisi yang mengendalikannya. Model-model kepemimpinan sekuler yang diktaktor dan otoriter adalah gambaran riil dari bagaimana presuposisi kepemimpinan sekuler dibangun dan berakhir. ${ }^{9}$ Penekanan pada sisi antroposentris dan visi yang pragmatis memberikan konfirmasi bahwa gagasan-gagasan teori kepemimpinan tersebut perlu dipertimbangkan secara seksama jika ingin diterapkan di dalam konteks kepemimpinan Kristen. Suatu pola kepemimpinan yang sama sekali berbeda karena berorientasi pada nilai-nilai spiritual, kualitas dan kuantitas iman jemaat. ${ }^{10}$

Di sisi lain model kepemimpinan Kristen dalam beberapa kasus disadari atau pun tidak, justru mengacu pada orientasi dan prinsip nilai yang dikembangkan dalam pola kepemimpinan sekuler. Sebagai contoh dalam beberapa kasus yang dikemukakan Cousin dimana ketika angka-angka menjadi alat ukur kesuksesan dan "yang diberkati," usaha pengembangan diri yang justru menghantarkan pada kebergantungan terhadap kekuatan diri sendiri, serta berkompromi dengan kebenaran demi meraup daya tarik pemimpin Kristen, ${ }^{11}$ adalah bentuk-bentuk sekularisasi kepemimpinan yang diadoposi dalam gereja. Ini merupakan realitas yang nampak pada pola kepemimpinan Kristen dengan pendekatan model kepemimpinan sekuler yang pragmatis. Hal ini juga dijelaskan Sanders bahwa pada zaman Rasuli, kepemimpinan Kristen disandarkan pada kasih yang murni kepada Kristus dan gereja-Nya, sementara pada masa kini, menjadi pemimpin Kristen berarti memperoleh martabat dan hak istimewa. ${ }^{12}$ Contoh lainnya, Burke mengatakan bahwa sebagai seorang pemimpin Kristen, ia seringkali berjuang untuk mencapai target dan sampai kepada puncak ketenaran sebelum pada akhirnya dikubur olehnya. ${ }^{13}$ Gambaran ini memperlihatkan perubahan fokus para pemimpin Kristen yang secara halus telah dipraktekkan di dalam gereja. Alasan-alasan pergeseran presuposisi kepemimpinan Kristen ini menurut Burke, salah satu alasannya karena telah terjadi pergeseran wawasan dunia manusia abat ke-21 yang merujuk pada

${ }^{9}$ Bambang Yudho, How To Become a Christian Leader: Prinsip-Prinsip Kepemimpinan Kristen (Yogyakarta: Andi, 2006), 11.

${ }^{10}$ Christopher Alexander et al., "Implementasi Gaya Kepemimpinan Yesus Sebagai RoleModel Dalam Kehidupan Pemuridan,” Jurnal Excelsis Deo Vol.5, No. (2021): 46.

11 Don Cousins, Experiancing Leadershift: Mengubah Pemahaman Mengenai Kepemimpinan (Malang: Gandum Mas, 2016), 48-53.

12 J.Oswald Sanders, Kepemimpinan Rohani (Bandung: Kalam Hidup, 2017).

${ }^{13}$ H. Dale Burke, How To Lead \& Still Have a Life (Malang: Literatur SAAT, 2014), 12. 
manusia sebagai sentral eksistensi hidupnya dan bukan Tuhan. ${ }^{14}$ Pergeseran ini kemudian juga berdampak pada pola kepemimpinan Kristen masa kini. Ketika orientasi kepemimpinan Kristen diletakkan pada gagasan dasar kepemimpinan sekuler yang mengabsenkan spiritualitas Alkitab dan penekanan yang kuat pada pragmatisme antroposentris, maka metode, tujuan dan etika kepemimpinan tidak lagi menjadi prinsip dan panduan utama kepemimpinan Kristen. Dalam konteks kepemimpinan Kristen demikian, penulis mengajukan usaha rekonstruksi kepemimpinan yang didasari pada spiritualitas Alkitabiah sebagai fondasi fundamentalnya.

Berdasarkan latar belakang tersebut, rumusan masalah dalam tulisan ini meliputi: Pertama, apakah yang dimaksud dengan spiritualitas Alkitabiah? Kedua, bagaimanakah perbandingan sistim nilai kepemimpinan Kristen dan sekuler? Ketiga, bagaimanakah penerapan spiritualitas Alkitabiah sebagai hakikat kepemimpinan Kristen masa kini? Tujuan penelitian ini mencakup: Pertama, untuk memahami kerangka spiritualitas yang Alkitabiah sebagai landasan kepemimpinan. Kedua, untuk mengetahui perbedaan nilai-nilai yang ada dalam sistim kepemimpinan Kristen dan sekuler. Ketiga, sebagai usaha untuk menerapkan model kepemimpinan Kristen yang berbasis pada Alkitab. Ada pun manfaat penelitian adalah untuk memberikan koreksi positif dan konstruksi pemahaman dalam usaha mendorong para pemimpin Kristen agar mampu mengembangkan model kepemimpinan yang berorientasi pada spiritualitas Alkitabiah.

\section{Metode Penelitian}

Penelitian ini mengunakan metode kualitatif deskriptif dengan pendekatan studi library research yang di dasarkan pada pegelolaan data dan informasi dari literatur-literatur. ${ }^{15}$ Teknik pengumpulan data menggunakan pendekatan penyelidikan terhadap buku-buku dan tulisan-tulisan karya ilmiah yang berkaitan dengan kepemimpinan, teologi, dan manajemen. Data-data yang bersifat teks tersebut dianalisis berdasarkan data-data Alkitab kemudian dilakukan kajian komparatif dengan pola penalaran induksi dan deduksi. ${ }^{16}$ Proses analisis data dengan pendekatan studi perbandingan dan komparasi

\footnotetext{
${ }^{14}$ Burke, How To Lead \& Still Have a Life.

${ }^{15}$ Sugiyono, Metode Penelitian Kuantitatif Kualitatif Dan $R \& D$ (Bandung: Alfabeta, 2019), 6,9.

${ }^{16}$ Andreas B. Subagyo, Pengantar Riset Kuantitatif Dan Kualitatif (Bandung: Kalam Hidup, 2014), 118.
} 
dalam rangka menemukan gagasan-gagasan inti kedua pola kepemimpinan. ${ }^{17}$ Analisis kritis juga diterapkan terhadap asumsi-asumsi yang membentuk presuposisi kepemimpinan untuk menemukan prinsip-prinsip serta nilai-nilai dasar apa saja yang melatar belakangi model kepemimpinan Kristen dan sekuler. Sementara pengambilan kesimpulan didasarkan pada penalaran logis terhadap premis-premis metodologis dan analisis tersebut.

\section{Pembahasan dan Hasil}

\section{Spiritualitas Alkitabiah}

Kata "spiritualitas" secara etimologi berasal dari akar kata spare (Latin) yang berarti: menghembus, tiupan, aliran angin. Dari kata kerja spare terbentuk kata benda spiritus atau spirit yang berarti udara, hawa yang dihirup, nafas hidup, nyawa, roh, hati, sikap, perasaan, kesadaran diri, kebesaran hati dan keberanian. ${ }^{18}$ Spiritualtas berkaitan erat dengan esensi, nilai-nilai dan cara pandang mengenai manusia seutuhnya dalam totalitas eksistensi di dunia. ${ }^{19}$ Dalam konteks Alkitab, istilah "spirit" dalam bahasa asli yang digunakan adalah ruakh (Ibrani) dan pneuma (Yunani) yang memiliki arti "nafas atau angina yang menggerakan dan menghidupkan." 20 Istilah spiritual sebagai kata sifat dari kata benda roh (spirit) secara implisit menjadi semacam jembatan antara unsur yang sakral dan profan. Intinya adalah bahwa di dalam hal-hal duniawi atau sekuler sekalipun, masih bisa ditemukan unsur spiritualitasnya atau lebih tepat dapat dijumpai dan diterapkan nilai-nilai wawasan dunia Kristen. ${ }^{21}$ Pandangan Alkitab erat mengaitkan dengan karya dan kuasa Roh Kudus ${ }^{22}$ sehingga istilah spiritualitas kemudian dimaknai sebagai sumber semangat untuk hidup, bertumbuh dan berkembang dalam semua bidang kehidupan di dunia ini, baik

${ }^{17}$ Anton Baker dan Achmad Charris Zubair, Metodologi Penelitian Filsafat (Yogyakarta: Kanisius, 1994), 83-85.

${ }^{18}$ Haryadi Baskoro and Hendro H. Siburian, "Keseimbangan Antara Spiritualitas Dan Intelektualitas Dalam Pelayanan Pastoral-Karismatik," FIDEI: Jurnal Teologi Sistematika Dan Praktika 2, no. 1 (2019): 123-44, https://doi.org/10.34081/fidei.v2i1.37.

${ }^{19}$ Martina Novalina, "Spiritualitas Orang Kristen Dalam Menghadirkan Kerajaan Allah Di Tengah Tantangan Radikalisme," Jurnal Teologi Kontekstual Indonesia Vol.1, No. (2020): 33.

${ }^{20}$ Asnath N. Natar, Spiritualitas \& Pelayanan, Asnath N. (Yogyakarta: Taman Pustaka Kristen, 2012), 7.

21 Daniel Syafaat Siahaan, "Pendidikan Kristiani Sebagai Instrumen Penyadaran Pentingnya Pertumbuhan Spiritualitas Dalam Konteks Budaya Populer," GEMA TEOLOGIKA, 2016, 129, https://doi.org/10.21460/gema.2016.12.218.

${ }^{22}$ Hendro H. Siburian Haryadi Baskoro, "Keseimbangan Antara Spiritualitas Dan Intelektualitas Dalam Pelayanan Pentakostal-Karismatik," Fidei Vo.2 No.1 (2019): 128. 
secara pribadi maupun bersama orang lain yang diperolah melalui perjumpaan pribadi dengan Allah, sesama dan diri sendiri. ${ }^{23}$ Atau seperti yang dikemukakan secara singkat oleh Tanudjaja, "spiritualitas Kristen yang sejati adalah keberadaan seseorang yang berada di dalam relasi yang benar dengan Allah, sesama, dan ciptaan lainnya." 24

Dalam kaitannya dengan kepemimpinan, terlihat jelas bahwa spiritualitas seorang pemimpin merupakan aspek kunci yang membentuk wawasan dunianya dalam proses kepemimpinan. Semua pemimpin akan membangun konsep kepemimpinannya berdasarkan suatu "spiritualitas," baik konsep spiritualitas Alkitabiah, maupun spiritualitas yang non Alkitabiah (sekuler/humanistik dan nilai-nilai religius non Kristen). ${ }^{25}$ Ciri spiritualitas ini mengendalikan wawasan dunia kepemimpinan dan termanifestasikan dalam ragam gagasan maupun kebijakan yang diaktualisasikan.

\section{Perbandingan Kepemimpinan Kristen dan Sekuler}

Dalam proses analisis ini penulis menggunakan dua pendekatan perbandingan, yang pertama, rumusan yang dirumuskan oleh penulis menyangkut perbandingan perihal: motif, metode, etika, dan tujuan (analisis MMET) yang merujuk pada uji presuposisi kepemimpinan. Sementara yang kedua adalah tabel perbandingan Sanders yang merujuk pada uji karakteristik fenomena yang nampak pada model kepemimpinan. Yang pertama mengkaji presuposisi seorang pemimpin, sementara yang kedua mengkaji fenomena kepemimpinan.

Di dalam tabel pertama (gambar 1), empat elemen MMET dipergunakan sebagai instrumen dan indikator untuk membedakan prinsip-prinsip utama sekaligus untuk menguji kepemimpinan Kristen dengan kepemimpinan sekuler. Motivasi, metode, etika dan tujuan kepemimpinan merupakan unsur-unsur fundamental yang mendasari bentuk praksis kepemimpinan seseorang. Dalam proses analisa tersebut dijumpai dua model gagasan presuposisi kepemimpinan sebagai berikut:

${ }^{23}$ Natar, Spiritualitas \& Pelayanan.

${ }^{24}$ Rahminati Tanudjaja, Spritualitas Kristen \& Apologetika Kristen (Malang: Literatur SAAT, 2018), 19.

${ }^{25}$ Novalina, "Spiritualitas Orang Kristen Dalam Menghadirkan Kerajaan Allah Di Tengah Tantangan Radikalisme." 
190 Fidei: Jurnal Teologi Sistematika dan Praktika, Vol. 4, No. 2, Des. 2021

Gambar 1. Tabel Analisa MMET

\begin{tabular}{cll}
\hline $\begin{array}{c}\text { Analisa } \\
\text { MMET }\end{array}$ & Kepemimpinan Kristen & Kepemimpinan Sekuler \\
\hline Motivasi & Teosentris & Egosentris/Antroposentris \\
\hline Metode & Alkitabiah & Filsafat \\
\hline Etika & Kerajaan Allah & Sekularisme \\
\hline Tujuan & Visi dan kemuliaan & $\begin{array}{l}\text { Visi dan kemuliaan } \\
\text { pribadi (subjektivitas dan } \\
\end{array}$ \\
& Allah & pragmatisme) \\
\hline
\end{tabular}

Analisa MMET pada tabel tersebut memperlihatkan perbedaan presuposisi yang signifikan dari model kepemimpinan Kristen dan sekuler. Hal mendasar dari metode hingga tujuan semuanya berpusat pada diri sendiri, filsafat dan unsur-unsur pragmatis sebagai tujuan akhirnya. Perbedaan-perbedaan ini menjadi indikator penting untuk menguji prinsip-prinsip presuposisi kepemimpinan seorang kristiani. Sementara untuk memahami perbedaan karakteristik antara kepemimpinan spiritualitas Alkitabiah (atau rohani) dan kepemimpinan sekuler (atau alami), penulis mengutip bagan yang diajukan oleh J. Osword Sanders dalam bukunya "Kepemimpin Rohani," ${ }^{26}$ sebagai berikut:

Gambar 2: Tabel Perbandingan Pemimpin Alami dan Rohani.

\begin{tabular}{ll}
\hline Pemimpin Alami (Sekuler) & Pemimpin Rohani (Alkitabiah) \\
\hline Percaya kepada diri sendiri & $\begin{array}{l}\text { Percaya kepada Allah dan } \\
\text { mengenal Allah }\end{array}$ \\
\hline Mengambil berbagai & Berusaha mencari kehendak \\
keputusan sendiri & Allah \\
\hline Ambisius & Tidak menonjolkan diri \\
\hline Menciptakan cara-caranya & Mencari dan mengikuti cara \\
sendiri & Allah \\
\hline Suka menyuruh orang lain & Suka menaati perintah Allah \\
\hline Didorong oleh pertimbangan- & Didorong oleh kasih kepada \\
pertimbangan pribadi & Allah dan manusia \\
\hline Berdiri sendiri & Bergantung kepada Allah \\
\hline
\end{tabular}

${ }^{26}$ Sanders, Kepemimpinan Rohani. 
Dalam analisa tabel yang diajukan oleh Sanders, kepemimpinan alami (atau sekuler) memberikan ciri serta indikator serupa yaitu, pragmatis dan antroposentris. Hal-hal ini dapat diuji pula dengan rumusan yang diajukan penulis pada tabel sebelumnya. Dari ketujuh ciri yang dikemukakan Sanders, jika diterapkan dalam penggunaan rumusan MMET maka akan dijumpai hasil bahwa kepemimpinan sekuler tetap memuat presuposisi sekuler-pragmatis dan antroposesntris - dalam aktualisasi kepemimnnan. Perbandingan rincian analisisnya sebagai berikut: $M$ (motivasi): Egosentris (lih. poin ke-1 - 7). M (metode): Filsafat (lih. poin 4, 6). E (etika): Sekularisme (lih. poin. 4, 6). T (tujuan): Visi pribadi (lih. poin 2-4). Penekanan pragmatisme dan egosentris terlihat jelas dalam pola kepempinan sekuler sekaligus membedakannya dengan pola kepemimipinan Kristen. Hal ini secara eksplisit menunjukkan perbedaan signifikan antara kedua model kepemimpinan tersebut sekaligus memperlihatkan keunggulan dari penerapan spiritualitas alktabiah sebagai model kepemimpinan Kristen karena mengacu pada sistem nilai Alkitab yang bukan hanya mampu mentransformasi personal leader, namun juga pada relasinya dengan dunia kerja.

Perbandingan yang disajikan tersebut dapat menjadi gambaran singkat mengenai perbedaan prinsip-prinsip kepemimpinan Kristen dan sekuler, sekaligus dapat menjadi input serta kritik positif bagi kepemimpinan Kristen masa kini. Melalui serangkaian perbandingan nilai-nilai serta rumusan yang ada, para pemimpin Kristen dapat menguji dan mengoreksi pola-pola kempimpinan mereka sesuai dengan prinsip-prinsip kebenaran Alkitab. Spiritualitas kepemimpinan Kristen tentu perlu dibangun di atas dasar serta nilai-nilai kebenaran firman Tuhan, baik penerapan kepemimpinan umat Tuhan di dalam gereja, perusahaan, maupun di dalam struktur lembaga/organisasi masyarakat lainnya, perangkat nilai dan wawasan dunia Kristen harus menjadi sistem penggeraknya. Meski demikian, penekanan utama penulis dalam kajian ini bukanlah semacam isu dualisme antara kepemimpinan Kristen dan kepemimpinan sekuler yang mana seolah-olah terdapat pertentangan dalam semua aspek di antara keduanya. Dalam prinsip-prinsip kepemimpinan sekuler juga terdapat manifestasi dan fragmnetasi dari nilai-nilai kebenaran Biblis yang bersifat universal seperti karakter, relasional serta prinsip kerja dan pelayanan yang baik. Hal ini dapat djumpai dalam beberapa studi integratif yang sementara 
diusahakan ${ }^{27}$ dan salah satunya yang cukup baik adalah model sevent leadership yang digagas oleh Gary E. Roberts. ${ }^{28}$ Penekanan penelitian ini lebih merujuk pada rekonstruksi dan kritik bagi model kepemimpinan Kristen kontemporer yang mengabaikan spiritualitas Alkitabiah.

\section{Permasalahan Kepemimpinan Kristen Masa Kini}

Perbedaan yang kontras mengenai prinsip nilai serta presuposisi kepemimpinan Kristen dan sekuler menimbulkan ragam permasalahan dalam area praksisnya. Manifestasi dari spiritualitas pragmatisme yang kuat dalam teori kepemimpinan sekuler menjadikan para pemimpin Kristen tertekan oleh karena beragam tuntutan mengenai model kepemimpinan ideal yang dikemukakan dan yang diadopsi dari teori-teori tersebut, umumnya di-framing sebagai model unggulan satu-satunya bagi konsep kepemimpinan Kristen. ${ }^{29}$ Kecenderungan gagasan mengenai kepemimpinan ideal tersebut pada akhirnya membentuk sebuah persepsi bahwa,

Kunci menuju kesusksesan adalah Anda harus menjadi seorang pemimpin yang hebat. Kesusksesan didasarkan pada kemampuan Anda untuk memimpin. Jika Anda memiliki "karunia tersebut" maka Anda memiliki masa depan yang menjanjikan. Jika tidak, maka mulailah menghadiri setiap konferensi kepemimpinan dan mulailah membaca setiap buku kepemimpinan yang bisa Anda dapatkan - karena jika Allah tidak menjadikan Anda seorang "pemimpin yang berkarunia," Andalah yang harus menjadikan diri Anda seperti itu. ${ }^{30}$

Sistem nilai perihal kepemimpinan yang dikonstruksikan dalam masyarakat saat ini berkembang menjadi semacam sistem nilai multak dengan kesusksesan pragmatis sebagai summum bonumnya. Manifestasi dari gagasangagasan pragmatis sekuler tersebut ikut menyusup secara halus dalam eksistensi gereja, membentuk pola-pola kepemimpinan dan karakteristik kepemimpinan Kristen masa kini. ${ }^{31}$ Gambaran ini terlihat dari prinsip kesuksesan kepemimpinan Kristen selalu diukur dengan pencapaian hal-hal pragmatis serta

${ }^{27}$ Nicodemus Yuliastomo and Ivan Th.J Weismann, "Kepemimpinan Gembala: Suatu Kajian Filosofis Tentang Proses Integrasi Kepemimpinan Rohani Dan Sekuler," Jurnal Jaffray, 2010, 19, https://doi.org/10.25278/jj71.v8i1.38.

${ }^{28}$ Gary E. Roberts, Developing Christian Servant Leadership: Faith-Based Character Growth at Work (New York: Palgrave Macmillan, 2015), 1.

${ }^{29}$ Cousins, Experiancing Leadershift: Mengubah Pemahaman Mengenai Kepemimpinan.

${ }^{30}$ Cousins.

${ }^{31}$ Yahya Wijaya, "Kepemimpinan Yesus Sebagai Acuan Bagi Kepemimpinan Gereja Masa Kini,” Jurnal Jaffray, 2018, 130, https://doi.org/10.25278/jj71.v16i2.287. 
fenomena-fenomena yang berkaitan dengan kuantitas semata. Cousins menjelaskan, "Barangkali ini bisa menjelaskan mengapa pelayanan-pelayanan besarlah yang hampir selalu menyelenggarakan berbagai konferensi mengenai pelayanan. Mereka memiliki sesuatu untuk diajarkan kepada kita semua. Bagaimanapun juga, angka-angka mereka memberitahu kita: Mereka berhasil!"32 Kondisi kepemimpinan yang menekankan pada nilai-nilai pragmatis tersebut berimplikasi pada timbulnya persoalan di kemudian hari karena membebani dan memaksa para pemimpin Kristen menjadi "manusia super" yang di sisi lain justru terbatas dalam banyak hal. ${ }^{33}$ Gambaran lain dari model integratif yang dikutip Yunianto dari Barna mengenai 33 karakter Kristus dan 21 kecakapan yang perlu dimiliki pemimpin Kristen ${ }^{34}$ cukup ideal. Meski demikian secara implisit gagasan ini tetap saja menekankan sisi pragmatis antroposentris karena tujuan akhirnya adalah keberhasilan pragmatis dimata orang-orang yang dipimpin dan bukan di mata Tuhan. Bahkan model integrasi kepemimpinan hamba yang dipandang sangat baik pun pada realitasnya tidak dapat diterapkan sepenuhnya dalam dunia kerja karena terdapat ketegangan diantara sistem nilai yang bertolak belakang dan sangat membebani serta menguras tenaga seorang pemimpin Kristen. ${ }^{35}$

Dalam konteks dunia kerja, kepemimpinan Kristen yang mengintegrasikan elemen kepemimpinan sekuler dengan nilai-nilai Alkitab, kerap kali kurang menjanjikan keuntungan-keuntungan pragmatis sebagaimana model kepemimpinan sekuler, khususnya dalam konteks kepemimpinan professional (kepemimpinan Kristen non gerejawi). Persaingan industri yang dipenuhi prinsip serta nilai-nilai sekuler, memaksa para pemimpin Kristen (baik dalam konteks individu maupun organisasi/perusahaan) untuk kembali menggunakan prinsip-pinsip sekuler sebagai alternatif akhir. Boa menemukan hal ini pada pengalaman para pengembang Kristen yang mengintegrasikan prinsip bisnis dan kepemimpinan berbasis Alkitabiah namun ketika pasar sepi, pengembang tersebut justru meninggalkan kota dan semua tanggung jawabnya bagi para investor. ${ }^{36}$

\footnotetext{
${ }^{32}$ Cousins, Experiancing Leadershift: Mengubah Pemahaman Mengenai Kepemimpinan.

${ }^{33}$ Burke, How To Lead \& Still Have a Life.

${ }^{34}$ Petrus Yunianto, "Kualitas Kepemimpinan Yosua," Fidei Vol. 1 No. (2018): 177-78.

${ }^{35}$ Burke, How To Lead \& Still Have a Life.

${ }^{36}$ Kenneth Boa, The Perfect Leader (Malang: Gandum Mas, 2009), 19.
} 
Demikian halnya dalam kepemimpinan gerejawi persoalan-persoalan demikian masih dijumpai. Perselisihan-perselisihan persoalan asset, ${ }^{37}$ perselisihan persoalan pergantian jabatan pemimpin dan penggembalaan jemaat, ${ }^{38}$ model kepemimpinan tunggal yang tanpa kontrol hamba Tuhan sejawat (penekanan pada pengkultusan ketokohan dan senioritas yang berlebihan), ${ }^{39}$ serta serangkaian persoalan kepemimpinan lainnya di dalam gereja saat ini, mengkonfirmasikan fenomena rumit antara kuatnya pengaruh pragmatisme dan lemahnya nilai-nilai spiritualitas kepemimpinan yang Alkitabiah baik dalam level kelembagaan gerejawi maupun personal leader. Dari permasalahn ini juga dapat dilihat bahwa masih terdapat gap sistem nilai antara konsep kepemimpinan Kristen dalam konteks gerejawi (gembala/pemimpin divisi/sel sebagai leader) yang dilakukan dengan prinsip pelayanan "suka rela non profit" serta konsep kepemimpinan Kristen konteks non-gerejawi (manejer/owner perusahaan/ organisasi sebagai leader) yang dilakukan dengan strategi bisnis menuju pencapaian maksimal profit. Kendala ini menunjukkan lemahnya penerapan spiritualitas Alkitabiah dalam kepemimpinan Kristen serta belum adanya sintesa kepemimpinan Kristen yang universal dan konsisten.

\section{Spiritualitas Alkitabiah Sebagai Hakikat Kepemimpinan Kristen}

Kegagalan-kegagalan dalam kepemimpinan Kristen kontemporer dapat ditelusuri dari inti permasalahan mendasarnya yaitu spiritualitas sebagai seorang Kristen. Spiritualitas berkaitan erat dengan keyakinan iman yang kemudian berdampak pada praksis karakter, etika dan moralitas pemimpin. Spiritualitas Kristen merupakan keselarasan antara apa yang diyakini dan praktek hidup ${ }^{40}$ sebagai seorang pemimpin sehingga hal ini merupakan suatu tuntutan iman dalam penerapan praksisnya (ortopraksi). Harris menjelaskan, "Kesehatan spiritualitas kita adalah inti dari diri kita sendiri. Ketika kita berada dalam relasi yang benar dengan Allah, dengan orang lain, dengan dunia ciptaan dan dengan diri sendiri, berarti kita sedang berada dalam posisi menerapkan kepemimpinan

${ }^{37}$ Dahlan Iskan, “Alex Susul Leonard,” www.disway.id, 2020.

${ }^{38}$ Afdhalul Ihksan, "Duduk Perkara Jemaat HKBP Cibinong Ricuh, Bermula Dari Pelantikan Pendeta Baru," regional kompas.com, 2020.

${ }^{39}$ Haryadi Baskoro, "Keseimbangan Antara Spiritualitas Dan Intelektualitas Dalam Pelayanan Pentakostal-Karismatik."

${ }^{40}$ Kalvin S. Budiman, "Habitus Dalam Mengikut Kristus: Kaitan Antra Etika Karakter Dan Spiritualitas Kristen,” Veritas Vol. 12 No (2011): 145. 
yang sehat." ${ }^{41}$ Harris memperlihatkan unsur krusial spiritualtas sebagai hal utama kepemimpinan Kristen yang justru tidak dijumpai dalam teori-teori kepemimpinan sekuler. Untuk itu singnifikansi penerapan spiritualitas Kristen dalam konteks kepemimpinan perlu diterapkan. Penulis mengemukanan tiga prinsip dasar sebagai alasannya, yaitu:

Pertama, spiritualitas Kristen merupakan ekspresi dari wawasan dunia Alkitab yang termanifestasikan dalam semua aspek kehidupan orang percaya sehingga mereka dapat menjadi terang dan garam dunia serta mempermuliakan Allah (Mat. 15:14-16). Henry dan Richard Blackaby menjabarkan hal ini dengan mengatakan, "Kerajaan Allah adalah, sebenarnya, pemerintahan Allah dalam setiap aspek kehidupan manusia, termasuk gereja, rumah tangga, tempat kerja, dan lingkungan tetangga. Mengabaikan kebenaran-kebenaran ini ketika memasuki dunia bisnis atau arena politik berarti membahayakan diri sendiri." ${ }^{2}$ Cakupan aspek spiritualitas di dalam keyakinan iman Kristen meliputi segenap aspek kehidupan orang percaya. Panggilan pelayanan kristiani tidak pernah dan tidak boleh dibatasi oleh tembok-tembok gereja. Spiritualitas yang memancarkan kemuliaan Allah itu harus ditempatkan di atas "kaki dian sehingga menerangi semua orang" dan "mempermuliakan Bapa di sorga" (Mat. 5:15-16). Mengulas pemikiran John Calvin mengenai pemanfaatan ciptaan Allah secara benar, Mark Shaw menjabarkan prinsip ketiga perihal pertanggungjawaban (accountability) yang berarti bahwa,

Kita menyadari bahwa Allah akan menghakimi kita sehubungan dengan cara-cara kita memanfaatkan karunia ciptaan maupun budaya. Oleh karena itu, tidaklah cukup bagi kita untuk melakukan tugas dengan baik hanya ketika diawasi oleh atasan kita. Kita bekerja bagi Tuhan kita yang senantiasa mengawasi pekerjaan kita. Suatu kejujuran etis dan keadilan sosial hendaknya senantiasa menjadi perhatian para pekerja Kristen, karena Allah juga menaruh perhatian pada hal-hal demikian. ${ }^{43}$

Pertanggungjawaban moral dalam hal pelayanan dan pekerjaan sosial juga merupakan bagian dari spiritualitas Kristen yang Alkitabiah, demikian halnya dengan sorang pemimpin Kristen. Spiritualitas demikian berakar dari kebenaran firman Tuhan yang mendasari prinsip kerja dan spiritualitas pemimpin Kristen

${ }^{41}$ Brian Harris, Kura-Kura Bisa Menang: Refleksi Alkitabiah Tentang Kepemimpinan Yang Tenang Bagi Para Pemimpin Yang Enggan Menjadi Pemimpin (Bandung: IOTA Press, 2014), 108.

${ }^{42}$ Henry dan Richard Blackaby, Kepemimpinan Rohani (Jakarta: Gospel, 2009), 29.

${ }^{43}$ Mark Shaw, Sepuluh Pemikiran Besar Dari Sejarah Gereja (Surabaya: Momentum, 2009), 63. 
oleh karena, "Apapun juga yang kamu perbuat, perbuatlah dengan segenap hatimu seperti untuk Tuhan dan bukan untuk manusia. Kamu tahu, bahwa dari Tuhanlah kamu akan menerima bagian yang ditentukan bagimu sebagai upah. Kristus adalah tuan dan kamu hamba-Nya" (Kol. 3:23-24). Spiritualitas Alkitabiah yang sejati mengajarkan umat Tuhan terutama para pemimpin Kristen untuk melaksanakan tugas dan tanggungjawab mereka dengan baik tanpa jatuh kepada sikap kemunafikan yang menipu diri sendiri. ${ }^{44}$

Kedua, semua karakter yang benar bersumber dari Allah dan karya Roh Kudus. Prinsip-prinsip ini dijumpai dalam kebenaran Alkitab pada surat Galatia 5:25, "Jikalau kita hidup oleh Roh, baiklah hidup kita juga dipimpin oleh Roh." (TB); Since we live by the Spirit, let us keep in step with the Spirit (NIV); If we live in the Spirit, let us also walk in the Spirit (NKJV). Alkitab versi TB menggunakan kata "dipimpin" untuk merujuk pada pola kehidupan kristiani yang telah dihidupkan (lahir baru) oleh Roh Kudus. Sementara versi NIV menggunakan kata step (melangkah), demikian juga dalam versi NKJV kata yang digunakan adalah walk (berjalan) bersama/dalam Roh Kudus. Dalam versi Yunaninya GRK: $\pi v \varepsilon v ́ \mu \alpha \tau \imath ~ \kappa \alpha i ̀ ~ \sigma \tau o \imath \chi \tilde{\omega} \mu \varepsilon v$. Kata $\sigma \tau o \imath \chi \tilde{\omega} \mu \varepsilon v$ (stoicheó) dalam ayat ini berarti to be in rows, to walk by rule. Kata kerja ini dari kata dasar

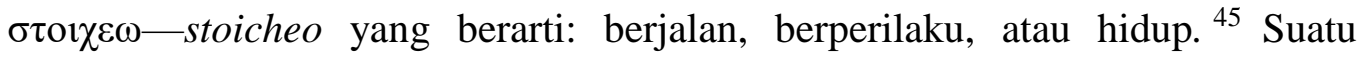
penegasan dan perintah agar kehidupan orang percaya (spiritualitasnya) harus berjalan secara teratur dalam aturan dan pimpinan Roh Kudus dengan mengenakan buah roh (ay. 22-24), menyalibkan hawa nafsu daging (ay. 25), tidak gila hormat dan menjadi pengacau (ay. 26). Kebenaran ini mengemukakan prinsip fundamental bahwa karakter yang berkenan kepada Allah tidak dihasilkan dari manusia, namun dari karya Roh Kudus dan firman-Nya. Karakter yang sejati dilahirkan dari pertobatan, pengenalan dan pimpinan Allah Roh Kudus. Sanders mengungkapkan bahwa kepemimpinan rohani atau dalam konteks tulisan ini menyangkut spiritualitas Alkitabiah berkaitan dengan kuasa yang lebih tinggi nilainya, yang tidak bisa muncul dengan sendirinya selain melalui pimpinan dan kuasa Roh Kudus. Lebih jauh Sanders menegaskan bahwa baik campur tangan ilahi (kuasa Roh Kudus) maupun sifat-sifat alami kepemimpinan, tidak pernah timbul begitu saja, melainkan dianugerahi oleh Allah. ${ }^{46}$ Mempertegas landasan perihal spiritualitas kepemimpinan Kristen, Rubin Adi Abraham memberikan dua perikop pokok Alkitabiah menyangkut hal

\footnotetext{
${ }^{44}$ Shaw, Sepuluh Pemikiran Besar Dari Sejarah Gereja.

${ }^{45}$ Yayasan Lembaga Sabda, "SABDA: Online Bible Versi Indonesia," n.d.

${ }^{46}$ Sanders, Kepemimpinan Rohani.
} 
ini. Pertama, di dalam Keluaran 18:21 yang menyatakan lima karakteristik spiritualitas pemimpin Kristen dengan memiliki lima ciri integirtas: Integritas diri, integritas rohani, integritas sosial, integritas ekonomi, dan integritas kerja. Kedua, di dalam 1 Timotius 3:1-13 yang mencakup enam hal pokok ini menyangkut karakterisktik yang baik dalam aspek: Sosial, moral, mental, kepribadian, rumah tangga, dan kedewasaan. ${ }^{47}$ Keseluruhan karakteristik kepemimpinan berbasis Alkitab ini didasarkan atas karya Allah semata.

Ketiga, karena karakter, nilai-nilai dan prinsip-prinsip kepemimpinan sekuler tidak dapat dijadikan dasar kepemimpinan Kristen secara mutlak sebab dibangun di atas nilai-nilai filsafat dan kebudayaan sekuler, bukan kebenaran Allah. Memulai analisa sosiologi dan antropologi kepemimpinan, Kartono menjelaskan bahwa,

Dalam kekompleksan masyarakat demikian, manusia harus hidup bersama-sama dan bekerja sama dalam suasana yang tertib dan terbimbing oleh pemimpin; dan tidak bisa hidup menyendiri. Maka demi efisiensi kerja dalam upaya mencapai tujuan bersama, dan untuk mempertahankan hidup bersama, diperlukan kerja kooperatif. Dan semua kegiatan kooperatif dan karya budaya (aktivitas membuat budaya) itu perlu diatur, perlu dipimpin. ${ }^{48}$ (penekanan oleh penulis).

Dalam dorongan antropologi dan sosiologi kerja, nilai-nilai kepemimpinan dibentuk. Keseluruhan hal ini menyangkut tujuan-tujuan pragmatis. Karakteristik tersebut memperlihatkan bahwa baik metode, visi, tujuan, maupun karakter yang "baik" dari seorang pemimpin, keseluruhannya dibangun di atas dasar nilai-nilai sekularisme, dan dengan titik tolak demikian kepemimpinan pasti tidak akan menghasilkan kekuatan metodologi dan prinsip etika kepemimpinan Kristen yang benar. Thoha bahkan menegaskan bahwa secara umum tulisan yang membahas mengenai kepemimpinan akan berakhir pada kesenangan (pragmatisme dan egosentris subjektif). Hal tersebut dapat dimengerti karena manusia selalu membutuhkan pemimpin dan di setiap periode, kepemimpinan akan selalu menjadi tumpuan harapan manusia. ${ }^{49}$ Pemimpin Kristen yang membangun visi, nilai dan karakternya di atas dasar nilai-nilai sekuler, tidak dapat bertahan menghadapi tantangan oleh karena dasar serta sistem nilai yang digunakan hanya berpaut pada sistem nilai dunia yang

${ }^{47}$ Rubin Adi Abraham, Kepemimpinan Dan Manajemen Gereja (Bandung: Sekolah Tinggi Teologi Kharisma, n.d.), 9-10.

${ }^{48}$ Kartono, Pemimpin Dan Kepemimpinan: Apakah Kepemimpinan Abnormal Itu?

${ }^{49}$ Miftah Thoha, Kepemimpinan Dalam Manajemen (Depok: Rajawali Press, 2015), 3. 
mudah berubah, relatif, dan kompromi sesuai dengan pergerakan filsafat dan kebudayaan manusia. ${ }^{50}$

Kecenderungan-kecenderungan ini mengkonfirmasi bahwa kepemimpinan Kristen tidak dapat dipisahkan dari spiritualitas Alkitabiah. Sekali lagi, spiritualitas Alkitabiah yang mencakup sistem nilai Kerajaan Allah harus menjadi fondasi dasar kepemimpinan Kristen yang paling fundamental.

\section{Penerapan Prinsip Sriritualitas Alkitabiah dalam Kepemimpinan Kristen}

Pendekatan prinsip-prinsip spiritualitas Alkitabiah yang dapat diterapkan dalam konsep kepemimpinan Kristen dalam tulisan ini meliputi dua hal, pertama, prinsip spiritualitas Alkitabiah itu sendiri dan yang kedua, empat pokok dasar presuposisi kepemimpinan sebagaimana analisa MMET (Motivasi, Metode, Etika, Tujuan) yang dapat disingkat dengan rumusan SA+MMET. Spiritualitas Alkitabiah (SA) menjadi landasan eksistensi kehidupan spiritual pemimpin, sementara empat elemen MMET merupakan presuposisi yang olehnya kepemimpinan Kristen dibangun.

Penerapan bagian pertama: Prinsip spiritualitas Alkitabiah (SA). Spiritualitas Alkitabiah/Kristen dan presuposisinya yang secara lebih sprsifik dijelaskan oleh Sandra M. Schneiders sebagai berikut;

Christian spirituality as Christian specifies the horizon of ultimate value as the triune God revealed in Jesus Christ to whom Scripture normatively witnesses and whose life is communicated to the believer by the Holy Spirit making her or him a child of God. This new life, which Paul calls "life in the Spirit" (cf. Rom. 7: 6; 8: 2, 6, 10-11; Gal. 6: 8) is celebrated sacramentally within the believing community of the church and lived in the world as mission in and to the coming reign of God. This life of faith and disciple ship constitutes the existential... Christian spirituality. ${ }^{51}$

Seperti definisi tersebut, spiritualitas Alkitabiah/Kristen menghubungkan kehidupan umat Tuhan pada imannya kepada Allah Tritunggal dan firman-Nya serta dalam aktualisasi eksistensinya. Secara teologis spritualitas Alkitabiah adalah keseluruhan eksistensi hidup umat Tuhan yang dilahir barukan dan dipimpin oleh Roh, menghasilkan buah Roh dan memiliki kehidupan yang beroientasi pada kemuliaan Tuhan. Seorang pemimpin Kristen perlu mengembangkan kehidupan spiritualitasnya sebagai dasar dari

${ }^{50}$ Burke, How To Lead \& Still Have a Life.

${ }^{51}$ Sandra M. Schneiders, "Approaches to the Study of Christian Spirituality," in The Blackwell Companion to Christian Spirituality, ed. Arthur Holder (Malden: Blackwell Publishing, 2005), 17. 
kepemimpinannya. Mengembangkan praksis spiritualitas Kristen yang digagas Calvin, Mark Shaw memberikan enam "kebiasaan orang Kristen yang efektif" sebagai ciri spiritualitas Kristen: Pertama, bergantung pada Roh Kudus. Kedua, menyangkal diri. Ketiga, memikul salib. Keempat, memfokuskan diri pada kekekalan. Kelima, memanfaatkan seluruh aspek kehidupan bagi kemuliaan Allah. Keenam, bertekun dalam doa. ${ }^{52}$

Spiritualitas Alkitabiah tidak hanya berkaitan dengan penghayatan serta relasi iman dengan Tuhan yang bersumber dari kebenaran Alkitab (ortodoksi), namun juga menyangkut sisi praktik kehidupan (ortopraksi) dalam seluruh aspek kehidupan orang percaya, termasuk perihal kepemimpinan. Spiritualitas Alkitabiah bercirikan salib Kristus yang berdasarkan pada relasi dengan Allah (vertikal) dan ciptaan-Nya (horizontal) berdasarkan nilai-nilai kebenaran Alkitab. ${ }^{53}$ Dalam pemaparan prinsip kepemimpinan Kristen, Burke memulai dengan meletakan dasar spiritualitas sebagai landasan utama kepemimpinan. Ia mengatakan, "Spiritualitas memantapkan sang pemimpin pada intisari kehidupan, memperkuat karakter dan menyediakan tuntutan moral yang amat dibutuhkan bagi pemimpin... kita harus menancapkan jangkar iman dan kebijaksanaan kita pada Allah. Spiritualitas adalah titik temu yang menghubungkan antara kehidupan dengan kepemimpinan." ${ }^{54}$ Dari pemaparan ini terlihat secara eksplisit bahwa spiritualitas Kristen yang Alkitabiah tersebut merupakan esensi iman yang dimanifestasikan dalam segala aspek kehidupan orang percaya. Spiritualitas pemimpin Kristen perlu menekankan integrasi antra esensi (being) dan praksis (doing) dalam segala aspek kehidupan. ${ }^{55}$ Pemimpin yang memiliki relasi dengan Allah dan refleksi terhdap firman-Nya dengan baik, akan berdampak pada penerapan kepemimpinan dan relasinya dengan sesama (orang yang dipimpin). Tanpa spiritualitas Alkitabiah, pemimpin Kristen bukan hanya gagal dalam hal kepemimpinannya namun juga dalam hal imannya, oleh karena spiritualitas Alkitabiah adalah komponen dari ekspresi iman yang terlihat dalam kehidupan semua orang percaya, terutama seorang pemimpin Kristen.

Penerapan bagian kedua: Prinsip motivasi, metode, etika, tujuan (MMET). Bagian ini penulis akan menjabarkan secara singkat keempat prinsip tersebut.

${ }^{52}$ Shaw, Sepuluh Pemikiran Besar Dari Sejarah Gereja.

${ }^{53}$ Firman Panjaitan, "Kepemimpinan Yesus Kristus Sebagai Model Dasar Kepemimpinan Kristen Berdasarkan Matius 20:20-28," KINAA: Jurnal Kepemimpinan Kristen Dan Pemberdayaan Jemaat 1, no. 2 (2020), https://doi.org/10.34307/kinaa.v1i2.14.

${ }^{54}$ Burke, How To Lead \& Still Have a Life.

55 Yornan Yosef Nasrani Masinambow, "Pendidikan Kristiani Sebagai Sarana Pembentukan Spiritualitas Generasi Milenial," Pesca Vol. 17 No (2021): 67. 
Pertama, motivasi kepemimpinan Kristen harus bertolak dari sisi teosentris. Di posisi mana motivasi kepemimpinan diletakan (teosentris ataukah egosentiris/antroposentris), akan menjadi penentu arah kepemimpinan. Unsur utama yang menjadi dasar prinsip ini adalah persoalan motivasi yang teosentris. Motivasi adalah jendela worldview seorang pemimpin yang olehnya ia menentukan metode, etika, moralitas, dan tujuan yang hendak ia tuju. Darmaputera mengatakan, "Kualitas kepemimpinan, pada gilirannya, sangat ditentukan oleh motivasi. Hanya motivasi yang baik yang bisa melahirkan pemimpin yang baik! Seperti Cuma benih yang baik, yang dapat menghasilkan tanaman yang baik." ${ }^{56}$ Demikian halnya yang dilakukan dan diteladankan oleh Kristus, orientasi kepemimpinan dan pelayanan-Nya berpusat pada Bapa (Yoh. 5:36; 12:49; 17:21). Ketika motivasi kepemimpinan Kristen diletakan pada dasar Alkitabiah yang berpusat pada Allah (teosentris) maka pemimpin pun akan berpaut pada nilai-nilai kebenaran Allah di dalamnya.

Kedua, metode kepemimpinan Kristen harus menggunakan pendekatan yang juga berpusat pada Alkitab. Maksud dari metode kepemimpinan dengan pendekatan yang berpusat pada Alkitabiah dalam hal ini bertolak dari prinsipprinsip kebenaran Alkitabiah sebagai landasan serta cara-cara pendekatan kepemimpinan dan sekaligus sebagai filter terhadap metode pendekatan kepemimpinan sekuler. Alkitab menjadi sumber utama bangunan metodologi yang darinya prinsip-prinsip kepemimpinan seperti hal-hal spiritual, sifat-sifat, kecakapan-kecakapan, cara-cara dan skill menyangkut relasi dalam kepemimpinan dibangun. Alkitab juga sekaligus menjadi filter terhadap pendekatan metodologi kepemimpinan sekuler yang digunakan oleh seorang pemimpin Kristen. Jika suatu metode pendekatan kepemimpinan tidak sesuai dengan prinsip-prinsip kebenaran Alkitab, seorang pemimpin Kristen dapat mengoreksinya. Singkatnya, bagian ini menekankan pada koreksi semua metode yang digunakan untuk harus tunduk, lulus uji dan sesuai dengan prinsip-prinsip kebenaran Alkitab (Mzm. 119:105, 130, 160; Yoh. 17:7).

Ketiga, etika kepemimpinan Kristen harus merujuk pada etika Kerajaan Allah. Etika Kerajaan Allah merupakan prinsip etis yang mengikat eksistensi umat Tuhan. Maksudnya adalah bahwa seorang kristiani yang telah lahir baru di dalam Kristus, secara otomatis akan memasuki kehidupan di dalam pemerintahan "Kerajaan Allah." Sebuah sistem pemerintahan dimana kuasa,

${ }^{56}$ Eka Darmaputera, Kepemimpinan Dalam Perspektif Alkitab (Yogyakarta: Kairos, 2005), 27. 
perintah, dan otoritas Allah yang berdaulat dinyatakan atas umat-Nya, dunia serta alam semesta melalui Kristus. ${ }^{57}$ Etika Kerajaan Allah juga sekaligus merupakan prinsip serta tujuan hidup manusia sebagaimana rancangan Allah yang semula bagi kehidupannya. ${ }^{58}$ Di dalam sistem pemerintahan Kerajaan Allah tersebut, seorang Kristen tahu bahwa ia harus selalu mencari Kerajaan Allah sebagai prioritas hidupnya (Mat. 6:33). Itu artinya dalam praktik hidup sehari-hari ia memilih untuk hidup dengan cara yang lain dari orang dunia. ${ }^{59}$ Sebuah cara hidup yang berorientasi pada ketaatan mutlak pada kehendak, kedaulatan, dan kebenaran Allah sebagaimana etika kehidupan Kristus yang juga berorientasi pada Kerajaan Allah. ${ }^{60}$ Bertolak dari hal ini maka eksistensi kehidupan kristiani tidak pernah bebas nilai secara etik, demikian halnya dalam konteks kepemimpinan Kristen. Nilai-nilai Kerajaan Allah yang termanifestasikan di dalam kebenaran Alkitab, merupakan panduan etik yang wajib bagi semua pemimpin Kristen. ${ }^{61}$

Keempat, perihal tujuan kepemimpinan Kristen harus berorientasi pada visi dan kemuliaan Allah sebagai fokus utamanya. Tidak ada fokus tujuan lain dalam kepemimpinan Kristen selain berfokus pada visi dan kemuliaan Allah yang diringkas dalam konsep pengajaran perihal Kerajaan Allah oleh Kristus. Mangunhardjana menjelaskan, "Visi Yesus sebagai pemimpin adalah Kerajaan Allah. Rumusannya jelas, padat, singkat, mudah diingat dan diucapkan, maupun memberikan inspirasi, motivasi dan semangat untuk diwujudkan." ${ }^{62}$ Seperti Tuhan Yesus, tujuan kepemimpinan-Nya bertolak dan berakhir pada visi Kerajaan dan kemuliaan Allah, Bapa-Nya (Yoh. 17:4), demikian halnya dengan tujuan kepemimpinan Kristen (bdk. dgn, Mat. 5:16; Kol. 3:23). Seperti motivasi yang berorientasi pada Allah, maka tujuan kepemimpinan Kristen pun harus berorientasi pada Allah. Motivasi merupakan titik berangkat, sementara tujuan adalah titik akhir yang akan dicapai dalam kepemimpinan Kristen yaitu visi dan kemuliaan Allah. Motivasi dan tujuan yang berorientasi pada Allah akan

${ }^{57}$ David Kurniawan, Kerajaan Allah Di Antara Kita (Bandung: Kalam Hidup, 2006), 19.

58 J. Verkuyl, Etika Kristen: Bagian Umum (Jakarta: BPK Gunung Mulia, 2013), 274.

${ }^{59}$ J. Douma, Kelakuan Yang Bertanggung Jawab: Pembimbing Ke Dalam Etika Kristen (Jakarta: BPK Gunung Mulia, 2012), 79.

${ }^{60}$ Henk Ten Nepel, Jalan Yang Lebih Utama Lagi: Etika Perjanjian Baru (Jakarta: BPK Gunung Mulia, 2012), 9.

61 Arozatulo Telaumbanua, "Peran Gembala Sidang Sebagai Pendidik Dalam Pertumbuhan Rohani Jemaat," FIDEI: Jurnal Teologi Sistematika Dan Praktika 2, no. 2 (2019): 362-87, https://doi.org/https://doi.org/10.34081/fidei.v2i2.45.

62 A.M. Mangunhardjana, Yesus Pemimpin: Menggali Inspirasi Kepemimpinan Dari Praktek Dan Kinerjan-Nya (Yogyakarta: Kanisius, 2018), 33. 
mengikat keseluruhan komponen kepemimpinan Kristen, baik metode, etika, karakter, maupun hal-hal pendukung lainnya. Secara singkat, tujuan dari kepemimpinan Kristen terkait secara erat dengan visi Kristus baik menyangkut Kerajaan Allah, mempermuliakan Bapa, maupun amanat agung-Nya dimana semua orang percaya bertindak sebagai saksi yang diberi tugas untuk membawa kehidupan Kristus, "sampai ke ujung bumi" dalam segenap aspek kehidupan mereka. ${ }^{63}$ Dan tentu saja salah satu bentuk manifestasinya melalui gagasan utama dari tujuan kepemimpinan Kristen.

Penerapan spiritualitas Alkitabiah (SA) dan keempat komponen MMET tersebut merupakan presuposisi serta hakikat kepemimpinan Kristen yang paling fundamental. Dalam penerapan ini, hal-hal tambahan seperti skill kepemimpinan tidak menjadi sorotan utama oleh karena hal-hal tersebut hanya merupakan bagian komponen sekunder dan sekaligus merupakan konsekuensi logis dari ekspresi kepemimpinan Kristen yang berorientasi pada Allah. Demikian halnya dengan karakter pemimpin Kristen tidak menjadi fokus bahasan oleh karena secara implisit telah terakomodasi dalam spiritualitas Alkitabiah. Spiritualitas Alkitabiah merupakan pondasi bagi bagunan karakter pemimpin Kristen yang mempuni. ${ }^{64}$ Dengan demikian, penerapan prinsip-prinsip spiritualitas Alkitabiah dan komponen MMET merupakan hakikat yang harus dipenuhi dalam kepemimpinan Kristen masa kini, yang mana sekaligus berbeda dengan penekanan presuposisi kepemimpinan sekuler.

\section{Simpulan}

Berdasarkan analisa dan pembahasan di atas maka terdapat tiga kesimpulan yang penulis rangkum, yaitu: Pertama, spiritualitas alkitabiah selalu memiliki nilai unggul sebagai presuposisi kepemimpinan Kristen oleh karena sifatnya yang merestorasi subjek (pribadi pemimpin) dan objek (bawahan, lingkungan sosial dan dunia/alam) dengan nilai-nilai kebenaran Kerajaan Allah yang mempermuliakan-Nya. Kedua, terdapat perbedaan yang signifikan antara kepemimpinan Kristen dan kepemimpinan sekuler. Gagasan-gagasan umum yang dijumpai di dalam sistem kepemimpinan sekuler tidak dapat diterapkan secara mutlak pada model kepemimpinan Kristen masa kini. Ketiga, penerapan prinsip-prinsip kepemimpinan Kristen yang alkitabiah merupakan ekspresi spiritualitas kristiani yang sekaligus terkoneksi dengan praktik iman Kristen

${ }^{63}$ Boa, The Perfect Leader.

${ }^{64}$ Ryna Heppy Tambunan Sahat Martua Sinaga, "Prinsip Rendah Hati Dalam Kepemimpinan Yosua Sebagai Teladan Pemimpin Masa Kini," Harvester Vol. 6, No (2021): 2. 
dalam kepemimpinan. Sehingga menjadi jelas bahwa perihal kepemimpinan Kristen bukanlah sebuah wacana dualisme yang terpisah antara "pekerjaan/profesi sekuler" dan "pelayanan rohani," sebaliknya kepemimpinan seorang kristiani merupakan lingkup tanggungjawab pelayanannya demi mewujudkan nilai-nilai iman yang berorientasi pada Kerajaan Allah dalam dunia kerja.

\section{Daftar Pustaka}

Abraham, Rubin Adi. Kepemimpinan Dan Manajemen Gereja. Bandung: Sekolah Tinggi Teologi Kharisma, n.d.

Alexander, Christopher, Bait Adetya Aristo, Jonathan, Situmorang, and Tony Tedjo. "Implementasi Gaya Kepemimpinan Yesus Sebagai Role-Model Dalam Kehidupan Pemuridan.” Jurnal Excelsis Deo Vol.5, No. (2021).

Baskoro, Haryadi, and Hendro H. Siburian. "Keseimbangan Antara Spiritualitas Dan Intelektualitas Dalam Pelayanan Pastoral-Karismatik." FIDEI: Jurnal Teologi Sistematika Dan Praktika 2, no. 1 (2019): 123-44. https://doi.org/10.34081/fidei.v2i1.37.

Blackaby, Henry dan Richard. Kepemimpinan Rohani. Jakarta: Gospel, 2009.

Boa, Kenneth. The Perfect Leader. Malang: Gandum Mas, 2009.

Budiman, Kalvin S. "Habitus Dalam Mengikut Kristus: Kaitan Antra Etika Karakter Dan Spiritualitas Kristen." Veritas Vol. 12 No (2011).

Burke, H. Dale. How To Lead \& Still Have a Life. Malang: Literatur SAAT, 2014.

Clemmer, Jim. Sang Pemimpin: Prinsip Abadi Untuk Keberhasilan Tim Dan Organisasi. Yogyakarta: Kanisius, 2009.

Conner, Carol O'. Kepemimpinan Yang Sukses Dalam Seminggu. Jakarta: Indeks, 2014.

Cousins, Don. Experiancing Leadershift: Mengubah Pemahaman Mengenai Kepemimpinan. Malang: Gandum Mas, 2016.

Darmaputera, Eka. Kepemimpinan Dalam Perspektif Alkitab. Yogyakarta: Kairos, 2005.

Douma, J. Kelakuan Yang Bertanggung Jawab: Pembimbing Ke Dalam Etika Kristen. Jakarta: BPK Gunung Mulia, 2012.

Harris, Brian. Kura-Kura Bisa Menang: Refleksi Alkitabiah Tentang Kepemimpinan Yang Tenang Bagi Para Pemimpin Yang Enggan Menjadi Pemimpin. Bandung: IOTA Press, 2014.

Haryadi Baskoro, Hendro H. Siburian. "Keseimbangan Antara Spiritualitas Dan 
204 Fidei: Jurnal Teologi Sistematika dan Praktika, Vol. 4, No. 2, Des. 2021

Intelektualitas Dalam Pelayanan Pentakostal-Karismatik." Fidei Vo.2 No.1 (2019).

Ihksan, Afdhalul. "Duduk Perkara Jemaat HKBP Cibinong Ricuh, Bermula Dari Pelantikan Pendeta Baru." regional kompas.com, 2020.

Iskan, Dahlan. "Alex Susul Leonard." www.disway.id, 2020.

John C. Maxwell. 21 Ciri Pokok Seorang Pemimpin: Buatlah Orang Lain Ingin Mengikuti Anda. Surabaya: MIC, 2014.

Kartono, Kartini. Pemimpin Dan Kepemimpinan: Apakah Kepemimpinan Abnormal Itu? Depok: Rajawali Press, 2016.

Kurniawan, David. Kerajaan Allah Di Antara Kita. Bandung: Kalam Hidup, 2006.

Kyle, David T. The Four Power of Leadership. Batam: Kharisma Press, 2004.

Mangunhardjana, A.M. Yesus Pemimpin: Menggali Inspirasi Kepemimpinan Dari Praktek Dan Kinerjan-Nya. Yogyakarta: Kanisius, 2018.

Masinambow, Yornan Yosef Nasrani. "Pendidikan Kristiani Sebagai Sarana Pembentukan Spiritualitas Generasi Milenial." Pesca Vol. 17 No (2021).

Natar, Asnath N. Spiritualitas \& Pelayanan. Asnath N. Yogyakarta: Taman Pustaka Kristen, 2012.

Nepel, Henk Ten. Jalan Yang Lebih Utama Lagi: Etika Perjanjian Baru. Jakarta: BPK Gunung Mulia, 2012.

Novalina, Martina. "Spiritualitas Orang Kristen Dalam Menghadirkan Kerajaan Allah Di Tengah Tantangan Radikalisme." Jurnal Teologi Kontekstual Indonesia Vol.1, No. (2020).

Panjaitan, Firman. "Kepemimpinan Yesus Kristus Sebagai Model Dasar Kepemimpinan Kristen Berdasarkan Matius 20:20-28." KINAA: Jurnal Kepemimpinan Kristen Dan Pemberdayaan Jemaat 1, no. 2 (2020). https://doi.org/10.34307/kinaa.v1i2.14.

Roberts, Gary E. Developing Christian Servant Leadership: Faith-Based Character Growth at Work. New York: Palgrave Macmillan, 2015.

Sabda, Yayasan Lembaga. "SABDA: Online Bible Versi Indonesia," n.d.

Sahat Martua Sinaga, Ryna Heppy Tambunan. "Prinsip Rendah Hati Dalam Kepemimpinan Yosua Sebagai Teladan Pemimpin Masa Kini." Harvester Vol. 6, No (2021).

Sanders, J.Oswald. Kepemimpinan Rohani. Bandung: Kalam Hidup, 2017.

Schneiders, Sandra M. "Approaches to the Study of Christian Spirituality." In The Blackwell Companion to Christian Spirituality, edited by Arthur Holder. Malden: Blackwell Publishing, 2005. 
Shaw, Mark. Sepuluh Pemikiran Besar Dari Sejarah Gereja. Surabaya: Momentum, 2009.

Siahaan, Daniel Syafaat. "Pendidikan Kristiani Sebagai Instrumen Penyadaran Pentingnya Pertumbuhan Spiritualitas Dalam Konteks Budaya Populer." GEMA TEOLOGIKA, 2016. https://doi.org/10.21460/gema.2016.12.218.

Subagyo, Andreas B. Pengantar Riset Kuantitatif Dan Kualitatif. Bandung: Kalam Hidup, 2014.

Sugiyono. Metode Penelitian Kuantitatif Kualitatif Dan R\&D. Bandung: Alfabeta, 2019.

Tanudjaja, Rahminati. Spritualitas Kristen \& Apologetika Kristen. Malang: Literatur SAAT, 2018.

Telaumbanua, Arozatulo. "Peran Gembala Sidang Sebagai Pendidik Dalam Pertumbuhan Rohani Jemaat."FIDEI: Jurnal Teologi Sistematika Dan $\begin{array}{llll}\text { Praktika 2, no.2 (2019):362-87. } & \text { 2, }\end{array}$ https://doi.org/https://doi.org/10.34081/fidei.v2i2.45.

Thoha, Miftah. Kepemimpinan Dalam Manajemen. Depok: Rajawali Press, 2015.

Verkuyl, J. Etika Kristen: Bagian Umum. Jakarta: BPK Gunung Mulia, 2013.

Wijaya, Yahya. "Kepemimpinan Yesus Sebagai Acuan Bagi Kepemimpinan Gereja Masa Kini." Jurnal Jaffray,2018. https://doi.org/10.25278/jj71.v16i2.287.

Yudho, Bambang. How To Become a Christian Leader: Prinsip-Prinsip Kepemimpinan Kristen. Yogyakarta: Andi, 2006.

Yuliastomo, Nicodemus, and Ivan Th.J Weismann. "Kepemimpinan Gembala: Suatu Kajian Filosofis Tentang Proses Integrasi Kepemimpinan Rohani Dan Sekuler." Jurnal Jaffray, 2010. https://doi.org/10.25278/jj71.v8i1.38. Yunianto, Petrus. "Kualitas Kepemimpinan Yosua." Fidei Vol. 1 No. (2018).

Zaluchu, Sonny Eli. "Respons Tests Of Leadership Menurut Frank Damazio Pada Mahasiswa Pascasarjana Jurusan Kepemimpinan Kristen STT Harvest Semarang."Jurnal Jaffray $16 \quad$ (2018): 148. https://doi.org/https://ojs.sttjaffray.ac.id/index.php/JJV71/article/view/289. Zubair, Anton Baker dan Achmad Charris. Metodologi Penelitian Filsafat. Yogyakarta: Kanisius, 1994. 